\title{
Electrical conductivity method (EGM) stratigraphic dating of the Byrd Station ice core, Antarctica
}

\author{
C. U. Hammer, H. B. Clausen, \\ Department of Geophysics. The Niels Bohr Institute, University of Copenhagen, DK-2200 Copenhagen N, Denmark \\ C. C. LANGWAY, JR \\ Ice Core Laboratory, Department of Geology, State University of Nere York at Buffalo, Amherst, NY 14226, U.S.A.
}

\begin{abstract}
A continuous ECM profile (strong acid concentration) has becn measured along the $2191 \mathrm{~m}$ of ice core recovered at Byrd Station, Antarctica, in 1968. The ECM profile reveals continuous and systematic seasonal changes which are used for dating the ice core back to $50000 \mathrm{BP}$.Hammer and others: ECM stratigraphic dating of Byrd Station icc corc, Antarctica
\end{abstract}

\section{INTRODUCTION}

The ECM technique has been used to identify seasonal snow-accumulation layers in ice cores to great depths Hammer, 1983), and is a valuable interpretative tool in dating complicated ice-sheet chronologies, especially when used in conjunction with measurcments made on other physical and chemical parameters of the core Steffensen, 1988; Hammer, 1989). Unlike the volcanicdebris index horizons, the seasonality of acid peaks is mainly caused by a combination of seasonal changes in the sources of $\mathrm{H}_{2} \mathrm{SO}_{4}$ and $\mathrm{HNO}_{3}$ as exemplified for the Byrd Station corc by Hammer (1983)

\section{BAGKGROUND}

The Byrd Station, West Antarctica $\left(80^{\circ} \mathrm{S}, 120^{\circ} \mathrm{W}\right)$, decp ice core (BS68) is $2191 \mathrm{~m}$ long and represents the second continuous ice core drilled to bedrock through a polar ice sheet (Camp Century (1966) was the first). The vertical thickness of the ice sheet at Byrd Station is $2164 \mathrm{~m}$. The discrepancy bctwcen core length and vertical thickness is accounted for by the $15^{\circ}$ inclination measurement at the bottom of the borehole. At bedrock, the interface tcmpcrature of the ice is at the pressurc-melting point of $-1.8^{\circ} \mathrm{C}$ (Ueda and Garfield, 1969). The drill site is located about $600 \mathrm{~km}$ from the coast and $1530 \mathrm{~m}$ a.s.l. Today's mean annual surface temperature is $-28^{\circ} \mathrm{C}$ and the area receives about $10 \mathrm{~cm}$ w.e. precipitation per year (reported values range from 8 to $12 \mathrm{cmicca}^{-1}$ (Gow and others, 1972)). The low mean annual surface temperature at Byrd Station precludes the existence of summer temperatures above the melting point. Consequently, no disruption of summer snow layers takes place by melting nor has melting occurred during the recorded past. The BS68 core is essentially free of visibly observed melt features or dirt bands, but it did contain locally visibly derived volcanic ash layers from the Executive Range, West Antarctica (Gow and Williamson, 1971). Since it was recovered in 1968 , a variety of glaciochemical and climatic studies have been performed on the core e.g. Johnsen and others, 1972; Thompson and others, 1975; Cragin and others, 1977; Hammer, 1982; Palais and Legrand, 1985; Langway and others, 1988). Although these studies have added greatly to our knowledge of the climatic and paleo-environmental conditions existing during the Wisconsin ice age and the post-glacial Holocene period, most of the published scientific information was derived by performing sequential analyses on non-continuous or on selected depth intervals of the core. 'This was done because of both practical and tcchnical limitations, e.g. unsatisfactory core quality or continuity or restraints in techniques available at the time.

In contrast to the three Greenland deep ice cores from Camp Century, Dye 3 and Summit. the BS68 core contains a high acid content over the core interval represented by the Wisconsin icc agc. In the Arctic regions of the Northern Hemisphere, large amounts of unconsolidated loess and alkaline-earth materials were. swept from the continents and cxposed continental shclves during low sea levels and neutralized the acid atmospheric acrosol (Cragin and others, 1977; Hammer and others, 1980, 1985). A straight-forward detection of seasonal changes in acidity and acid volcanic signals by the clectrical ECM method (Hammer, 1980) is not possible in Greenland ice cores over the ice-core intervals covering glacial ages, because of their alkaline composition; the ECM can probably be used as a dating tool also for alkaline ice but this interesting possibility is beyond the scope of this paper and requires further studics on alkaline ice. The calibration curve used for the BS68 core was $\left[\mathrm{H}^{+}\right]=0.045 \cdot \mathrm{I}^{1.73}$, where $\mathrm{H}^{+}$is given in $\mu \mathrm{eq} \cdot \mathrm{kg}^{-1}$ and the electrical current in $\mu \mathrm{A}$. 
In addition, at some Greenland locations, such as Dye 3 , an average of almost $6 \%$ of the annual accumulation layers consist of summer melt features Herron and others, 1981), which also complicates the acidity record (Hammer and others, 1987; Clausen and Hammer, 1988; Clausen and Iangway, 1989).

However, in general, strong acids represent an important component of the total chemical constituents found in polar ice and the cores mirror major changes in the past atmospheric content of acidic trace gases such as $\mathrm{WO}_{x}, \mathrm{SO}_{x}$ and $\mathrm{HCl}$. This paper presents a stratigraphic dating of the Byrd Station core based on a study of continuous measurement of the atmospheric acidityconcentration levels inferred by using the ECM tech-nique on the BS68 core remaining at the time of the measurement (1982).

\section{SAMPLES}

Gertain depth intcrvals or sections of both the Grecnland and Antarctic cores when recovered were highly fractured and broken over an identifiable depth interval, the socalled "brittle zone" (Shoji and Langway, 1985). This brittle zonc is at least in part caused by clathrate-hydrate formation which takes place at a depth where a combination of high maximum stresses and minimum temperatures exist at their in-situ confining environment. Immediately after drilling, the core undergocs clastic recovery and, at the surface where the core is subjected only to ambient atmospheric pressure, severe fracturing of the core in the "brittle zone" occurs. Also, drilling fluid may seep into the inner part of the fractured ice core within the fractured zone. Removing the outer part of the ice core in this section is not always adequate to eliminate contamination. For this reason, the $300-880 \mathrm{~m}$ depth interval of the BS68 core could only be measured for acidity along a few short sample increments; a continuous acid-volcanic record is not available here. When the Dye 3 decp-ice core (D3/81) was drilled during the GISP 1979-81 operation (Dansgaard and others, 1982) and the GRIP drilling at Summit 1989-92 Johnsen and others, 1992), the occurrence of the brittle zone was anticipated and proper preparations led to a complete and satisfactory field measurement of acidity and the anions.

The BS68 core was drilled about 24 years ago and the acidity measurements for this study were made about 14 years later. As a consequence, the physical quality of the core had somewhat deteriorated due to stress relaxation and the slight temperature variations which occurred during its long transportation and storage (Shoji and Langway, 1985). This was also the case for the Camp Century, Grcenland, deep-ice core (GC66), which was analyzed for acidity and reported earlier Hammer and others, 1980). On a comparative basis, the BS68 core was originally recovered in a much better physical and continuous condition, and the acidity profile was made using a much-improved measuring technique than was the casc for the CC66 core study; except for the brittle zone, it was sufficient to remove only $1-2 \mathrm{~cm}$ from the outer part of the BS68 core to obtain reliable and reproducible ECM measurements.

\section{PROCEDURES}

The entire BS68 core was measured by the ECM at $23^{\circ} \mathrm{C}$ (the tcmperature in the cold-storage warehouse in Buffalo), except for about $50 \mathrm{~m}$ of selected ice-core sequences, which were also measured at both $-30^{\circ}$ and $12^{\circ} \mathrm{C}$ in the SUNY at the Buffalo Ice Core Laboratory. The laboratory measurements were made in order to estimate the activation energy $E_{\mathrm{a}}$ for the electrical conduction process. The calculated $E_{\mathrm{a}}$ was $0.23 \mathrm{eV}$. This value was used to calculate the current corresponding to $-14^{\circ} \mathrm{C}$, which was the temperature of the ice cores used for establishing the calibration curve. The acidity of the BS68 core was measurcd using the electrical d.c. conductivity method (now commonly called ECM), which is essentially a measure of the electrical current (Hammer, 1980). In principle, the ECM infers the acidity-concentration level in the ice core, whereas $\mathrm{pH}$ refers to measuremcnts made on melted samples. The difference is usually of little importance in interpreting Holocene ice deposits but, due to chemical reactions in the liquid state, the two acidity estimates may differ, especially when large amount of impurities are present. The latter case was of particular concern in the CC66 study, as the late Wisconsin ice-core samples were found to contain up to two orders of magnitude higher impurity content and particle concentrations than did the Holocene ice (Hammer and others, 1985). Conversely, the ECM measurements made over the glacial ice in the BS68 core, which has a much lower dust concentration, were found to follow the empirical $\left(\mathrm{H}^{+}\right)$ calibration curve of Hammer (1980). The calibration curve has later been found to vary somewhat from one drill site to another but no specific explanation has yet been found.

'The EGM measurements made over the 50000 year chronology provided more than $1.6 \times 10^{6}$ data points with a resolution of a few millimeters. Liquid-acidity (pH) and anion-concentration levels of important core sequences were measured and analyzed by $\mathrm{pH}$ and ion chromatography in both Buffalo and Copenhagen.

\section{DATING THE CORE}

The commonly low annual snow accumulation in Antarctica makes it difficult to use independently the $\delta^{18} \mathrm{O}$ method to determine accurately seasonal changes (Johnsen and others, 1972; Dansgaard and others, 1973). Various other indirect dating methods have been used in the past to date the BS68 core (Johnsen and others, 1972; Thompson and others, 1975; Lorius and others, 1981) but no acceptable systematic method previously existed for continuous stratigraphic dating the early Holocene and late Wisconsin of the ice core.

The top almost $88 \mathrm{~m}$ of the ice core from BS68 was recovered in an unsatisfactory physical condition which precluded using it for detailed laboratory analyses. In order to establish a proper reference horizon for our timescale, we first determined two fixed horizons; the AD 1968 snow surface and the AD 1259 volcanic-chemistry stratigraphic event (Langway and others, 1988). The AD 1259 layer lies $97.8 \mathrm{~m}$ below the AD 1968 surface reference. 


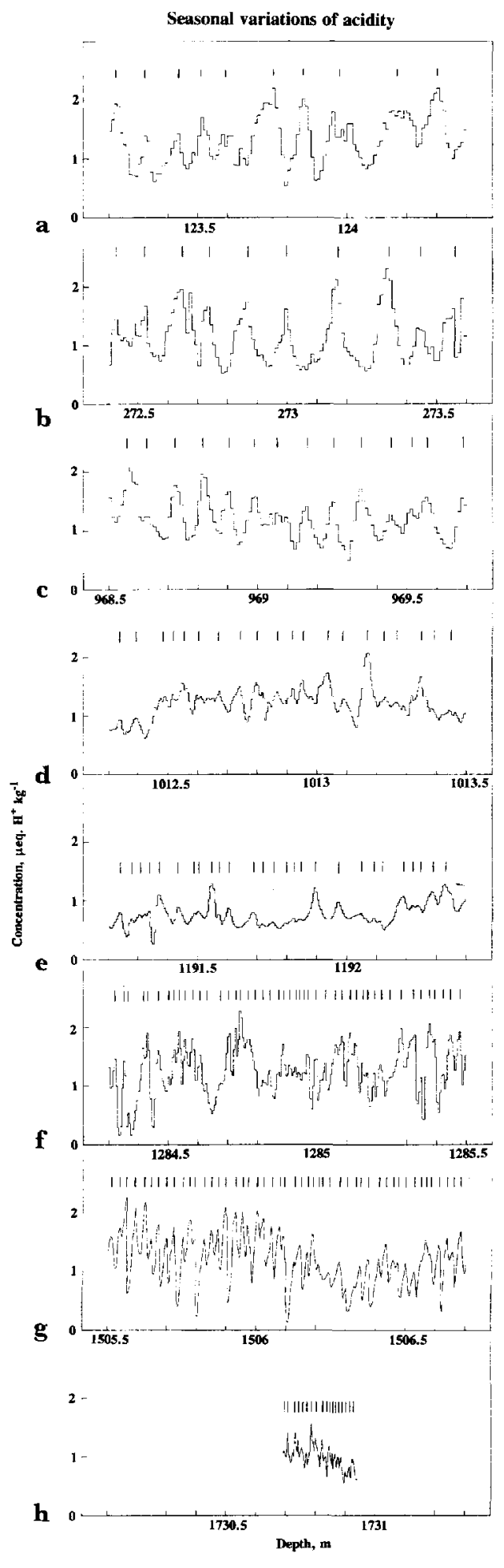

Fig. 1. The acidity measurements (FCM) in $\mu$ eq. $H$ $\mathrm{kg}^{-1}$ on the Byrd Station deep core (BS68). Figure la and $b$ are representalive curves of Holocene ice from above the "brittle zone". Figure $1 \mathrm{c}$ and $d$ are from Holocene ice below the "brittle zone". Figure le is from the Holocene. Wisconsin (H W) transition in the ice core. Figure If $h$ represent ice from the Wisconsin glaciation.

The ECM-resolution curves are plolted on azeraged $1 \mathrm{~cm}$ intervals for Figure $1 \mathrm{a}-\mathrm{c}$, with a resolution of $0.5 \mathrm{~cm}$ for Figure $1 d-f$ and with $0.2 \mathrm{~cm}$ for Figure $1 \mathrm{~g}-\mathrm{h}$. Each core section is $1.20 \mathrm{~m}$ in length but for Figure $1 \mathrm{~h}$ a shorter section is shown. The curdes show multiple-year annual acid layers $(\lambda s)$. Note the decreasing value of $\lambda$ s with depth.
Using the depth-density data for this core interval, we obtained an average annual accumulation-layer thickness, $\lambda$, of $11.2 \mathrm{~cm}$ of ice equivalent for the 709 years represented. A recent integrated study (Langway and others, 1994) on a new $164 \mathrm{~m}$ deep ice core recovered at Byrd Station in 1989 (NBY-89) provides us with a detailed up-to-date and continuous annual-layer stratigraphic chronology for the last 1360 years (1989-AD 629). An average icc-layer thickness, $\lambda$, of $11 \mathrm{~cm}$ of ice equivalent is given for this 1360 ycar time interval. The NBY-89 core time-scale and chemistry-stratigraphy also connect with the earlicr BS68 core records at several volcanic and chemical index horizons, including the prominent $\Lambda \mathrm{D} 1259$ event. These results substantiate our upper profile time-scale and further establish the AD 1259 event as a fixed, pronounced and reliable inter-hemispheric reference level for the new results presented here.

Figure 1 shows examples of the acid seasonal variations at several representative depths in the BS68 core. Systematic annual curves are very clear for all depth levels down to about $1600 \mathrm{~m}$. Below this depth, the scasonal signal becomes more complicated. 'This change is most probably related to the large increase in crystal size which begins here as a result of higher in-situ temperatures Gow and others, 1968) brought about by the geothermal heat flux and deformation. The systematic chronological record for the lower part of the core has been disturbed by non-laminar glacier flow over the rugged bedrock topography; the lowest $9 \mathrm{~m}$ of high-silt content basal icc, which is not included in our study, is probably much older than the immediate overlying ice; the high $\delta$ values (Johnsen and others, 1972) suggest that Eemian ice is present.

Figure 2 shows the $\delta^{18} \mathrm{O}$ curve (Fig. 2a), the ECM curve (Fig. 2b) and the interpreted annual ice-layer thickness $(\lambda)$ curve (Fig. 2c) for the core. Because of the missing $\lambda$ data in the brittle zone, our dating of the $B y r d$ Station corc was accomplished by an averaging process instead of using the actual $\lambda$ versus depth relationship. The three straight-line segments in Figure 2c represent hinge points where major changes in avcrage $\lambda$ s occur. The lines are based on the individual $\lambda$ s over the respective depth intcrvals. As shown, the $\lambda$ s decrease significantly but systematically with depth. The slope of the curve from near the surface downward shows a gradual decrcasc duc mainly to deformation until a sharper decrease occurs at about $1000 \mathrm{~m}$. The curve tends to flatten out to a lower rate of decrease at about $1300 \mathrm{~m}$ down to about $1910 \mathrm{~m}$. 'The curve has been extended to . the bedrock, as we have indications of seasonal variations down to around $2150 \mathrm{~m}$. 'The extended $\lambda$ curve does not intersect the origin at the bottom of the curve, probably because active melting occurs here and a value different from zero is to be expected. The slope of the curve between 18 and $50 \mathrm{kaBP}(1294-1910 \mathrm{~m})$ suggests that an average annual precipitation rate of about $5 \mathrm{~cm}$ of ice equivalent occurred at the surface during the late to mid Wisconsin (based on flow-dynamics considerations). The annual seasonal variations in acidity are observed down to about $1750 \mathrm{~m}$, corresponding to 40000 years $\mathrm{BP}$. Between 1750 and $1910 \mathrm{~m}$, the $\lambda$ s are still present but arc more difficult to resolve. We belicve that our dating of the ice-core record is valid and continuous to $1910 \mathrm{~m}$, 


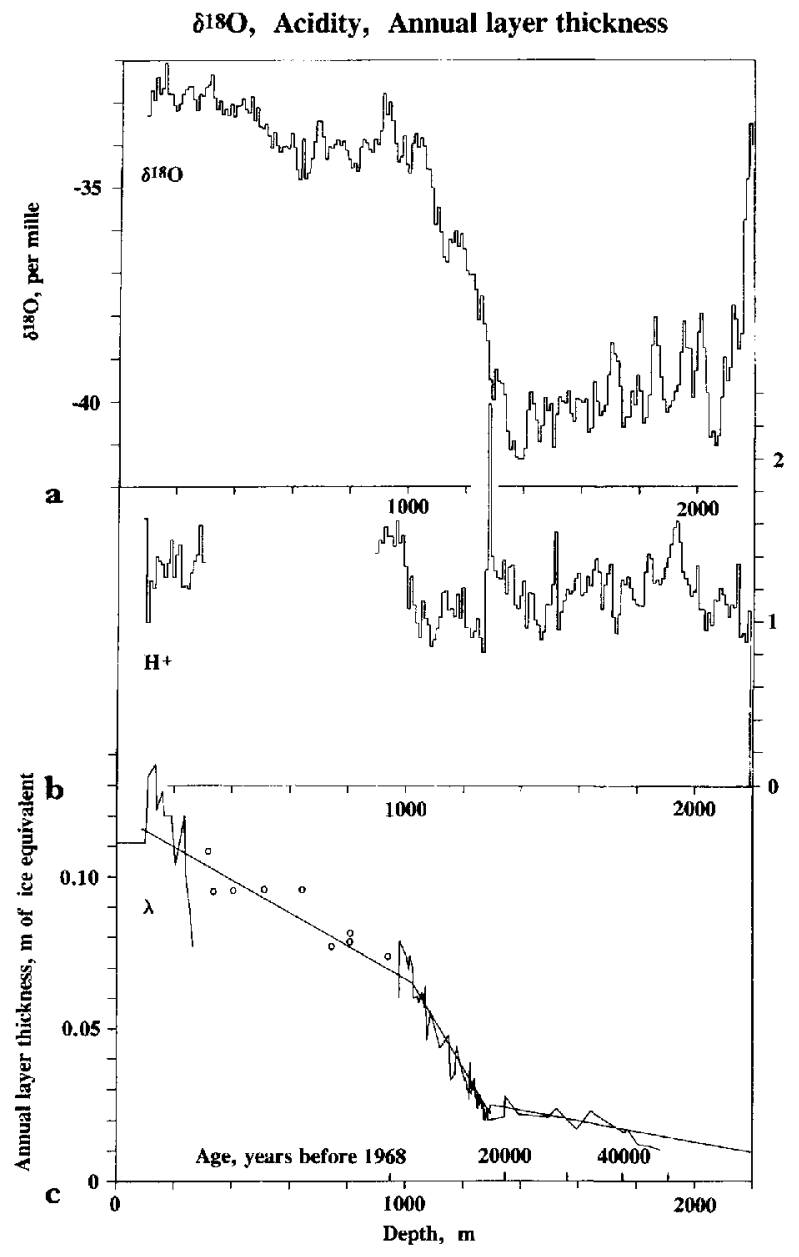

Fig. 2. The $\delta^{18} \mathrm{O}$ and ECM acidity-concentration values ploted as $10 \mathrm{~m}$ averages as depth and the $\lambda$ s for the BS68 core. Figure $2 a$ shows the $\delta^{10} O$ zalues in ppl and Figure $2 b$ showes the ECM acidily levels. An omission exists in the curce for Figure $2 b$ betzeen the surface and about $90 \mathrm{~m}$ (see text) and between 300 and $890 \mathrm{~m}$ (brittle zone). Figure $2 c$ show's the average annual ice-layer thickness curce $(\lambda)$. A fewe sequences could be used for detection of $\lambda$ in the brittle zone (circles) but not for absolule values of acidity.

corresponding to 50000 years BP. Any dating below $1910 \mathrm{~m}$ is probably lcss accurate.

There is, of course, a certain amount of subjectivity in identifying annual layers, e.g. in Figure 1, but the ECM "seasonals" can be followed continuously along the core and the corresponding " $\lambda \mathrm{s}$ " decrease with depth are as expected from flow-dynamical considerations, assuming a constant accumulation down to about $1000 \mathrm{~m}$.

The correctness and accuracy of the dating for the first $100 \mathrm{~m}$ are indicated by the integrated study of the NBY 89 and BS68 cores. Sequential IC chemical analysis clearly demonstrates that the seasonality of the ECM is almost entirely due to a strong seasonal cycle of $\mathrm{H}_{2} \mathrm{SO}_{4}$ and to a lesser extent to $\mathrm{HNO}_{3}$. The sulphate and nitrate actually seem to peak during the warm half-year of the Southern Hemispherc. Whilst there is some evidence for the ocean around West Antarctica as a source arca for the seasonally varying sulphuric acid (Prospero and others, 1991), the seasonal variation of the nitrate concentration is a more complex phenomenon to cxplain. This pronounced seasonality of nitrate is also clearly seen in Grcenland ice cores (Steffensen, 1988).

However, since nitrate and dust concentrations can be measured continuously and with high resolution along an ice core, we recently measured an increment of glacial ice from the BS68 core around $1285 \mathrm{~m}$ to check our annuallayer interpretation of the glacial ECM profile. The measurements showed that all three profiles indicate the same "average annual-layer thickness" over the core increment (to be published elsewhere). Still, there is a certain amount of subjectivity in the interpretation of the annual cycles of both ECM, dust and nitrate, which suggest that our dating precision of a 20000 year old ice layer is probably \pm 1000 years. Lsing the three straightlinc approximations shown in Figure $2 \mathrm{c}$, it is possible to express the age- depth relationship of the BS68 core in the mathematical equations given in Table 1. The accuracy of the time-scalc at the 11000 ycar BP level is approximately \pm 500 years; the high uncertainty is due mainly to the brittle zonc.

\section{THE $\delta$, EGM AND $\lambda$ PROFILES}

ligure 2 a shows $\delta^{18} \mathrm{Os}$ plotted for the entire BS68 core as $10 \mathrm{~m}$ averages. The $10 \mathrm{~m}$ averages depict a greater number of years as one descends in depth. The $\delta^{18} \mathrm{O}$. like $\lambda$ s are climatic parametcrs, which on average gradually decrease from the Holocene to the Wisconsin; they rapidly decrease during the Holocene/Wisconsin transition and fluctuate considerably but at lower (colder) levels in the Wisconsin ice age than in the Holocene period. There is, however, no clear indication that the shift in the $\delta^{18} \mathrm{O}$ values observed around $1080 \mathrm{~m}$ (corresponding to $12.1 \mathrm{ka} B \mathrm{P}$ on our scalc) coincides with the sharp decrease shown in $\lambda$ s (Fig. 2c). The dip in the $\delta$ s at $1005 \mathrm{~m}$ corresponds to an age of $10.9 \mathrm{ka} \mathrm{BP}$. In other words, the $\delta^{18} \mathrm{O}$ curve does not show an casily identified junction between the Holocene and the Holocene$W$ isconsin transitional zone. Note the $\pm 2-3 \%$ change of $\delta^{18} \mathrm{O}$ during the Holocene; this may partly be explained by upstream ice-flow conditions during the Holocene, which must be scrutinized before the Byrd Station and Arctic ice-core $\delta$ records can be compared in a more detailed way. Details and discussion of the entire $\delta^{18} \mathrm{O}$ have already been published (Johnsen and others. 1972). The Holocene-Wisconsin transition is identified as being approximately between $1080 \mathrm{~m}(12.1 \mathrm{ka} \mathrm{BP})$ and $1294 \mathrm{~m}$ (18.0 ka BP), a $214 \mathrm{~m}$ core interval which represents about 5900 years.

Figure $2 \mathrm{~b}$ shows a plot of the $10 \mathrm{~m}$ avcrage acidity values in $\mu \mathrm{eq} . \mathrm{H}^{+} \mathrm{kg}^{-1}$. The interval between 90 and $990 \mathrm{~m}$ shows higher average acid values than those measured in the Holocenc-Wisconsin transition and the Wisconsin age (between 18 and $50 \mathrm{ka} \mathrm{BP}$ ), although the Wisconsin ice has a relatively higher average-acidity level than the Holoccnc-Wisconsin transition. The off-scale acidity value between 1280 and $1290 \mathrm{~m} \quad(2.3 \mu \mathrm{eq}$. $\mathrm{H}^{+} \mathrm{kg}^{-1}$ ) is by far the single highest acidity value in the entire core the event is due to excessive volcanism and will be published in detail elsewhere).

The decrease in $\lambda$ s from the present day $11.2 \mathrm{~cm}$ of icc equivalent) to the end of the Holocene-Wisconsin 
transition $16.5 \mathrm{~cm}$ of ice equiralent is the result of thinning of beds load compaction and stretching of laversi. The arerage accumulation during the Holocene including the britule rote: is approximately $11.9 \mathrm{~cm}$ of ice equivalent. During the Holocene Wisconsin transition, the $\lambda$ s decrease in a step-like manner from about $6.5 \mathrm{~cm}$ at $102 \mathrm{tm}$ to about $2.5 \mathrm{~cm}$ just below $1294 \mathrm{~m}$ and. tinally, to about $1,5 \mathrm{~cm}$ at $1910 \mathrm{~m}$.

\section{DISGUSSION OF THE TIME-SGALE}

This study strongly indicates that scasonal periodicity of the background-level acid concentrations clearly persists over the BS68 core measured between 88 and $1910 \mathrm{~m}$ depths. Below this depth, annual acid layers are difficult to assess. Results of annual-layer-thickness analysis from the ECM measurements include the effect of thinning of beds due to flow deformation and the effect of climatic change as depicted in the $\delta^{18} \mathrm{O}$ curve. Based on the arguments presented above, it secms crident that the ECM profile has a strong seasonal character but other arguments. which substantiate this finding, can be brought into the discussion.

The reported low concentration levels of impurities in the core Thompson and others, 1975; Hammer, 1982; Palais and Legrand. 1985; Langway and others, 1988) rule out an impurity influence on the flow law as an explanation of the $\lambda$ changes during the HoloceneMisconsin transition. This explanation is confirmed by recent borehole measurements Hansen and others, 1989. It appeas that the annual precipitation in the Byrd Station area, and probably over the entire West Antaretic ice shect in general, increased about 2.5 times during the transition from the Iate-Glacial ice age to Holocene times. Similar rhanges in $\lambda$ s have been observed in the Greenland deep-ice cores Hammer and others, 1986: Johnsen and others, 1992), though the data for the Dye 3 and Camp Cicntury corcs are sparse.

Recent statistical studies of annual $\lambda / \delta$ ratios at various Greenland sites over the past 200 years (Clausen and others, 1988) show about an $8 \%$ change in the accumulation rate for each per mille change in $\delta^{18} \mathrm{O}$. This ratio is also derived from a precipitation model Johnsen and others, 1989; personal communication from $\mathrm{S}$. Johnsen. If this relation is applied to the approximately $7.5 \% \delta^{18} \mathrm{O}$ change orer the transition found in the Byrd Station core (Fig. 2a), one would expect a change in the annual precipitation by a factor of 2.5 .

Our results also indicate that a significant part of the enhanced ${ }^{10} \mathrm{~B}$ e concentrations found in ice cores over glacial times Raisbcck and othcrs, 1987; Beer and others, 1988) mainly reflect a lower rate of precipitation rather than incrcased ${ }^{10} \mathrm{Be}$ production in the atmosphere. The ${ }^{10} \mathrm{Be}$ concentration peaks observed in the Antarctic Dome $C$ and Vostok ice cores, and the Greenland Camp Century corc, probably have other explanations, and require further study to establish their bi-hernispheric significance as global reference horizons. ${ }^{10}$ Be measurements on the new Summit deep-ice corc from Grcenland should be able to solve this problem.

The dip in the BS68 $\delta^{10} \mathrm{O}$ curve around $12.1 \mathrm{ka} \mathrm{BP} \pm$ 0.5 ka could correspond to the Younger Dryas-Pre-Borcal (Y1)-PB time interval in the new Greenland Summit ice corcs. The sharp YD-PB transition in the Greenland cores (D3/81, CC66) has been dated as $10.750 \mathrm{ka} \mathrm{BP} \pm 0.15 \mathrm{ka}$ (Hammer and others, 1986) but, based on new data from Greenland, we obtained a value of $11.5 \mathrm{ka} \mathrm{BP} \pm 0.1 \mathrm{ka}$ Johnsen and others, 1992 ) and $11.6 \mathrm{ka} \mathrm{BP} \pm 0.3 \mathrm{ka}$ / Mllev and others, 1993;. It is also interesting to note that the BS68 annual-layer-thickness curve (Fig. 20) shows a dip around $1024 \mathrm{~m}$; this depth corresponds $1011.2 \mathrm{kaBP}$ in

Table 1. Dopth age mlationship. Calculated annual-layer thicknesses, $\lambda$, and ages, $t$, gizen field log-book depths, $d>150 \mathrm{~m}$. based on the linear decreasing zalues of the $\lambda s$ by depth over the three depth interats, shown in Figure 2c. The slope of the lines, $a, a n-5.432 \times 10^{5} a^{1},-15.93 \times 10^{5} a^{1}$ and $-1.7241 \times 10^{-5} a^{1}$, respectively. Those slopes are determined by hinge points in the interials. For the $10 p 1000 \mathrm{~m}$ of ice equivalent the subtracted $24 \mathrm{~m}$ corresponds to the amount of ain in the upper $150 \mathrm{~m}$ of fim layers, the hinge points are 0.11932 and $0.065 \mathrm{~m}$ of ice eq. a ${ }^{1}$. For the next $270 \mathrm{~m}$, the hinge poimts ane 0.065 and $0.222 \mathrm{~m}$ of ice eq. ${ }^{1}{ }^{1}$ and for $870 \mathrm{~m}$ of the last interval 0.025 and $0.010 \mathrm{~m}$ of ice eq. a! Thus. the age. $t_{1}$, at any depth, $d_{1}>150 \mathrm{~m}$, in the top interial, is determined by $t_{1}=\left(1 / \alpha_{1}\right)$ $\times \ln \left[1+\left(\alpha_{1} / 0.11932\right) \times\left(d_{1}-24\right)\right]$

Depth interial Ammat-lowe thickness, $\lambda$,
of
field log-book

m m of ice equivalent per year
Age, $i$,
at log-book deph
$d>1.50 \mathrm{~m}$
Age at bottom of
depth interial

vears before 1968

years before 1968

\footnotetext{
$150-102+-5.432 \times 10^{5} i d \quad 24+0.11932$

$1024-1294$

$15.93 \times 10^{3} d-1024+0.065$

$-\left(10^{5} / 5.432\right) \ln \left[1-\frac{.3 .132 \times 10^{-5}}{0.11932}(d-24)\right]$

11182

$1024-1294$

$11182-\left(10^{5} / 15.93\right) \ln \left[1-\frac{15.93 \times 10^{-5}}{0.065}(d-1024)\right]$

17984

$1294-2191.31$

$1.7241 \times 10^{5} d \cdots 1294+0.025$

$17984-\left(10^{5} / 1.7241\right) \ln \left[1-\frac{1.72+1 \times 10}{0.025}(d-1294)\right]$

$(73925)$
} 
our Byrd Station time-scale and could also correspond to the YD-PB boreal transition in Grecnland ice cores. However, the dating accuracy of the BS68 core does not allow a confident comparison between the "details" of the $\delta^{18} \mathrm{O}$ curve of the BS68 core and the corresponding Greenland records; the same applies to the Fast Antarctic deep ice cores from Vostok and Dome C (Lorius and others, 1979, 1985). Such a comparison would have to await new well-planned deep drilling in Antarctica.

\section{ACKNOWLEDGEMENTS}

The initial pilot study of the ECM investigation reported - here was made in 1980 and the complete measuring programme was conducted in 1982 in the commercial icecore-storage warehouse in Buffalo, New York. All of the original 2088 core tubes existing at that time were individually opened and the core remaining in the tubes was measured in the cold room over a $2 \frac{1}{2}$ month period. The authors regret the delay in publishing the full results but inadvertent postponements were experienced by new and often unrelated field and laboratory research obligations and divergent schedules. Some laboratory assistance for a variety of ionic chemistry measurements was made by K. Osada at the SUNY/Buffalo Ice Core Laboratory. We are indebted to the Danish Natural Science Research Council (SNF), the Commission for Scientific Research in Greenland (KVLG) and the U.S. National Science Foundation (NSF/DPP) for support covering various periods of the study.

\section{REFERENCES}

Alley, R.B. and 10 others. 1993. Abrupt increase in Grcenland snow accumulation at the end of the Younger Dryas event. Nature, $362(6420), 527-529$

Beer, J. and 6 others. 1988. Information on past solar activity and geomagnetism from ${ }^{10} \mathrm{Be}$ in the Camp Century ice core. Nature, $331(6158), 675-679$

Clausen, H. B. and O. L. Hammer. 1988. The Laki and I'ambora eruptions as revealed in Greenland ice cores from 11 locations. $4 \mathrm{~mm}$. Glaciol., 10, 1622.

Clausen, H. B. and C. C. Langway, Jr. 1989. The ionic deposits in polar ice cores. In Oeschger, H. and C.C. Langway, Jr, eds. The envirommenal record in glaciers and ise shaels. New York, etc., John Wiley and Sons, 225-217

Clausen, H. B., N. Gundestrup, S.J. Johnsen, R. Bindschadler and J. Zwally. 1988. Glaciological investigations in the Crête area, central Greenland: a search for a new deep-drilling site. Ann. Glaciol, 10, 10-15.

Cragin, J. H., M. M. Hcrron, C. C. Langway, Jr and G. Klouda. 1977. Interhernispheric comparison of changes in the composition of atmospheric precipitation during the late Cenozoic era. In Dunbar, M.J., ed. Conference at Montreal, 1974 Polar Oceans), 617.631.

Dansgaard, W.. S. J. Johnsen, H. B. Clausen and N. Gundestrup. 1973. Stable isotope glaciology. Medd. Gronl., 197/2), 1-53.

l)ansgaard, W. and 6others. 1982. A new Grecnland deep ice core. Science, 218 (4579;, 1273-1277.

Gow. A.J. and T. Williamson. 1971. Volcanic ash in the Antarctic ice sheet and its possible climatic implications. Earth Planet. Sci. Lett., 13(1), 210-218.

Gow, A.J., H. T. Ueda and D. E. Garfield. 1968. Antarctic ice sheet; preliminary results of first corc holc to bedrock. Science, $\mathbf{1 6 1}(3845)$, 10111013

Gow, A.J., F. de Blander, G. Crozaz and E. Picciotto. 1972. Snow accumulation at "Byrd" Station, Antarctica. 7. Glaciol, 11/61", 5964.

Hammer, C. L. 1980. Acidity of polar ice cores in relation to absolute dating, past volcanism, and radio-cchoes. F. Glaciol, 25 (93), 359-372.

Hammcr, C. L. 1982. The history of atmospheric composition as recorded in ice sheets. In Goldberg, E. D., ed. Atmospheric chemistry. Berlin, etc., Springer-Verlag, 119-134.

Hammer, C. U. 1983. Initial direct current in the build-up of space charges and the acidity of ice cores. 7 . Physical Chem., 87 (21), 4099-4103.

Hammer, C.U. 1989. Dating by physical and chemical seasonal variations and reference horizons. In Oeschger, $H$. and C.C. Langway, Jr, eds. The envirowmental recurd in glaciers and ice sheets. Chichester, etc., John Wiley and Sons, $99 \cdot 121$

Hammer, C. U., H. B. Clausen and W. Dansgaard. 1980. Grecnland ice sheet evidence of post-glacial volcanism and its climatic impact. Nature, 288, 230235.

Hammer, C.U., H.B. Clausen, W. Dansgaard, A. Neftcl, P. Kristinsdottir and E. Johnson. 1985. Continuous impurity analysis along the Dye 3 deep core. In Langway, C. C., Jr, H. Oeschger and W. Dansgaard, eds. Greenland ice core: geophrsics, geochemistry, and the environment. Washington, DC, American Geophysical Union, 90-94. (Geophysical Monograph 33.)

Hammer, C. U.. H. B. Clausen and H. Tauber. 1986. Ice core dating of the Pleistocene/Holocene boundary applied to a calibration of the ${ }^{14} \mathrm{C}$ time scale. Radiocarbon, 28 $2 \mathrm{~A}$ ), 284-291.

Hammer, C. U., H.B. Clausen, W. L. Friedrich and H. Tauber. 1987. The Minoan eruption of Santorini in Greece dated to $1645 \mathrm{BC}$. Nature, 328 6130$), 517-519$.

Hansen, B. L., J. R. Kelty and N. Gundestrup. 1989. Resurvey of Byrd Station drill hole, Antarctica. Cold Reg. Sci. Technol., 17(1), 1-6.

Herron, M.M., S. L. Herron and C.C. Langway, Jr. 1981. Climatic signal of ice melt features in southern Greenland. Nature, 293 (5831). 389-391.

Johnsen, S.J., W. Dansgaard, H. B. Clausen and C. C. Langway, Jr. 1972. Oxygen isotope profiles through the Antarctic and Greenland ice sheets. Nalure, 235(5339), 429-434 and 236, 249.

Johnsen, S. J.. W. Dansgaard and J. W. C. White. 1989. The origin of Arctic precipitation under present and glacial conditions. Tellus. $41 B(4), 452-468$.

Johnsen, S. J. and 9 others. 1992. Irregular glacial interstadials recorded in a new Greenland ice core. Nature, 359 6393), 31 1-313.

Langway, C. C., Jr, H. B. Clausen and C. U. Hammer. 1988. An interhemispheric volcanic time-marker in ice cores from Greenland and Antarctica. Ann. Glaciol., 10, 102-108.

Langway, C. C., Jr, K. Osada, H. B. Clausen, C. U. Hammer, H. Shoji and A. Mitani. 1994. New chemical stratigraphy for Byrd Station. Antarctica, over the last millennium. Tellus, Ser. B, 46B 1 ), 40-5l.

Lorius, C., L. Merlivat, J. Jouzel and M. Pourchet. 1979. A 30,000-rr isotope climatic record from Antarctic ice. Nature, 280, 644-648

Lorius, C., L. Merlivat, P. Duval, J. Jouzel and M. Pourchet. 1981. Evidence of climatic change in Antareric over the last 30,000 years from the Dome G ice core. In Allison, I., ed. International Association of Scientific Hydrology Publication 131 Sea level ice and climatic change!, 217-225.

Lorius, C. and 6 others. 1985. A 150,000 year climatic record from Antarclic ice. Nalure, 316(6029), 591-596.

Palais, J. M. and M. Legrand. 1985. Soluble impurities in the Byrd Station ice core, Antarctica: their origin and sources. 7 . Geophys. Res. 90(C1), $1143-1154$.

Prospero, J. M., D. L. Savoie, E.S. Saltzman and R. Larserl. 1991. Impact of oceanic sources of biogenic sulphur on sulphate aerosol concentrations at Mawson, Antarctica. . Kature, 350, 221 223.

Raisbeck, G. M., F. Yiou, D. Bourles, C. Lorius, J. Jouzel and N. I. Barkov. 1987. Evidence for two intervals of enhanced " $\mathrm{Be}$ deposition in Antarctic ice during the last glacial period. Nature, $\mathbf{3 2 6} 6110$. $273-277$.

Shoji, H. and C. C. Langway, Jr. 1985. Mechanical properties of fresh ice core from Dye 3, Grecnland. In Langway, C. C., Jr, H, Oeschger and W. Dansgaard, eds. Greenland ice core: geophesics, geochemistry and the environment. Washington, DC, Amcrican Geophysical Cnion, 39-48. (Geophysical Monograph 33.)

Steffensen, J.P. 1988. Analysis of the seasonal variation in dust, Cl, $\mathrm{NO}_{3}$, and $\mathrm{SO}_{4}{ }^{2}$ in two contral Gromland firn corcs. Ann. Glaciol. 10, $171-177$.

Thompson, L. G., W. L. Hamilton and C. Bull. 1975. Climatological implications of microparticle concentrations in the ice core from "Byrd" Station, Western Antarctica. 7. Glaciol, 14/72), 433-44t.

Ueda, H. T. and D. E. Garfield. 1969. Drilling through the Antarctic ice sheet. CRREI. Tech. Rep. 231

The accuracy of references in the lext and in this list is the responsibility of the authors, to whom queries should be addressed. 